\title{
Abdurrahman Wahid on the Public Role of Islam and Theory of Secularization
}

\author{
Saefur Rochmat ${ }^{1}$ \\ ${ }^{1}$ Department of History Education, the Faculty of Social Sciences, Yogyakarta State University, Yogyakarta, \\ Indonesia \\ Correspondence: Saefur Rochmat, Ph.D., Department of History Education, the Faculty of Social Sciences, \\ Yogyakarta State University, Karangmalang 55281 Yogyakarta, Indonesia. E-mail: Saefur_rochmat@uny.ac.id
}

Received: October 2, 2017

doi:10.5539/ass.v13n11p170
Accepted: October 9, $2017 \quad$ Online Published: October 28, 2017

URL: https://doi.org/10.5539/ass.v13n11p170

\begin{abstract}
As a cleric, Abdurrahman Wahid, the former president of Indonesia, was well versed with both the Islamic and the West civilization. Accordingly, he tried to synergize Islam with the development of modern era. In line with this, he tried to modify the theory of secularization to suit with the context of Indonesia in which Islam constitutes one of the major social political forces. The contextualization of Islam was not something new for the Muslims in their efforts to adjust to social system, including its political system. For that purpose Wahid employed the fiqh paradigm which is not ideological to the form of the state. In line with this he developed a mutual legitimacy between Islam and the Pancasila state that both should develop democracy as basic principle of modern state as well as the manifestation of the principles of syuro at modern era. In this regard, democracy constitutes an overlapping consensus between the state and the religion. Wahid considered it as substantive Syari'ah, as contrary to the legal formal Syari'ah. In line with this, religious communities take on a role in civil society which would provide checks and balances to the state.
\end{abstract}

Keywords: Abdurrahman Wahid; Islam; Indonesia; Secularization; Secularism.

\section{Introduction}

The Republic of Indonesia was established on $17^{\text {th }}$ August 1945 based on the national ideology of Pancasila, which is neither a secular state nor theocratic state, because of a gentlemen's agreement between the followers of a secular state and those of an Islamic state. This kind of political system is justified within the fiqh paradigm adopted by the traditionalist Muslims. It was considered as the best choice with respect to the unity and diversity of Indonesia. In this way, the Republic of Indonesia does not follow the pure concept of nation state, i.e. relegating religion to private affairs, but recognises the public role of religion. In this regard, Wahid differs from the moderate secularists such as Benyamin F. Intan and Jose Casanova who believe that: "the public roles of religion would be legitimate as long as they are addressed at the level of the discourse that occurs in civil society." (Benyamin F. Intan, 2006: 17-20). In this regard, Wahid believes that Islam should function within the public sphere holistically at various levels, including the national political level. For that purpose, he develops the substantial Syari'ah, a kind of liberal Syari'ah, which just concerns with the universal Islamic values such as democracy, justice, freedom, and equality.

The concept of liberal Syari'ah became more relevant in the aftermath of the end of the Cold War and the rise of global religious movements unified "by a common enemy of Western secular nationalism and a common hope for the revival of religion in the public sphere" (Benyamin F. Intan, 2006: 7). Since then, religions become one of the most important forces in international politics, negating Francis Fukuyama's belief of the 'end of history' that signifies the triumph of secular liberal democracy. Mark Juergensmeyer even saw it as a start of a new Cold War between the religionists and the secularists (Mark Juergensmeyer, 1994: 4). Last but not least, Samuel Huntington believed that the conflicts in post-Cold War world politics will no longer be driven by ideology or economy, but by a clash of civilisations, implying the unviability of the ideas of democracy and human rights beyond Western shores (Samuel P. Huntington, 1993: 23-24). For that purpose, Wahid offered a concept of democracy which is not ideological, a kind of liberal Syari'ah, relying not only on secular knowledge, but also religious knowledge. 


\section{Method}

Abdurrahman Wahid tried to develop political approach, not legal formal approach to the relationship between Islam and the state. As a kind of norm, Islam with its universal values should be critical to any systems, including political system. His view is in line with the fiqh paradigm which recognises the difference between religion, namely Islam, and culture, the manifestation of societal life. This implies that religion and culture, including politics, are different identities (Abdurrahman Wahid, 2001a: 27). In doing so, Wahid wanted to say that Islam is from the God, implying a sacred matter, meanwhile the state are created by people, implying a secular one. Consequently, the existence of the state is based on the existence of power in the society, not because of the existence of a sacred matter. Indeed, the state needs a justification from the sacred one to exist continuously. Accordingly, there should be a separation between the state leader and the religious leader in order to avoid the birth of autocratic political leader. For that purpose, religious leaders should play in a role of civil society, providing checks and balances to the state. In this regard Wahid proposed a substantive Syari'ah, namely Islamic universal values, which would enable the Muslim to participate actively in modern political system.

\subsection{Introduction}

What is meant by the secular state is that the state is not established based on religion; but this does not imply the clear-cut separation of the public and the private sphere, a problem that has continued to stimulate debate over the centuries between followers of secularism and disciples of religions (Stephen V. Monsma, 1996: 3-5). The followers of secularism argued that it was inappropriate to bring religious affairs into the public sphere and the state also should not give any help to religions, which they considered the private sphere. The radical secularists, even, persisted in their belief after the fall of the Berlin wall in 1989 which has instigated the revival of religions. In this regard Pippa Norris and Ronald Inglehart (2009: 14) just modified a little bit of the theory of secularisation by proposing a thesis of existential security where religion is still in need in developing countries because the people do not feel secure.

It is impossible to limit religion to just the matter of the private sphere, considering that religion consists of belief and practice in which the latter is subject to state regulation of religious practice under headings like public order, morality, health, and social activities. Under these categories some Western countries such as the United States of America, the United Kingdom and Australia give funds to non-profit organisations, and some of them are deeply religious in their character and practice. These non-governmental organisations are alive, growing, and play the role of civil society which supports the process of democratisation by assuming the role of checks and balances to the state. In the case of the USA, some observers have coined terms such as the 'third sector' and the 'third-party government' because it is a third phenomenon not accounted for by the public-private bifurcation with which most Americans are familiar (Stephen V. Monsma, 1996: 3-5). It is likely that the classical theory of secularisation believed by the founding fathers of social sciences such as August Comte and Max Weber was not based on strong empirical arguments and contained inconsistencies (Benyamin F. Intan, 2006: 12).

\subsection{Secularism versus Secularization}

Wahid did not agree with the classical theory of secularisation as a kind of secularism where the state develops a wall of separation between the state as public affairs and religion as private affairs. This ideological understanding of secularisation was developed by the secularists based on the assumption of three stages of the intellectual development of human beings that are myth, religion, and science. This implies an evolution of man's consciousness from the 'infantile' to the 'mature' state, and is defined by secularists as the removal of religious and metaphysical supports and putting man on his own (Abdurrahman Wahid, 1989: 15-16).

Wahid differentiated secularization from secularism as the latter is a kind of ideology which is menace to the former. Apart from his agreement with Syed Naguib al-Attas (1993: 19-20), a modernist Muslim, on the definition of secularism, he believed that secularization is not just peculiar to the Western civilisation. Moreover, he developed secularisation as a means to assist Islam to meet changes in society (Syed Naguib al-Attas, 1993). His theory of secularization was a kind of counter discourse to Kemmal Attaturk's secularism in Turkey (Abdurrahman Wahid, 1999d: 4). Indeed, he was critical of military regimes such as those of Kemal Attaturk, King Reza Syah, Gamal Abdul Nasser, and Suharto who modernised the country following a top-down model which did not encourage the political participation of the people. In this regard, Attaturk was only able to maintain his power because of his autocratic rule, (EkramBadr El-din \& Mohamed Dit Dah Ould Cheikh, 2017: 75) and his followers were not able to convince the people to support the Republican People's Party (CHP) since general election in 1950. However, Turkey was ruled by a constitution along purely secular lines so the religiously inspired people were not able to participate actively in the process of modernisation (Adam Schwarz, 
1994: 187).

Wahid judged correctly that the failure of military regimes' effort at modernising the country to be caused by their ignorance of Islam, not employing Islam as a source of values in national political life. In this regard he followed at the path of Japanese model of modernisation which recognised Japanese tradition as the source of values (Abdurrahman Wahid, 1999d: 71). In line with this, Islam as a source of values could be taken into consideration in the course of modernisation. Wahid persuaded Muslims to differentiate between secularisation and secularism. He argued that basically Muslims were agreed on the rejection of secularism, however, they were divided between those who wanted to adopt partial accommodation to secularism, namely in the form of secularisation, and those who had totally rejected secularism (Abdurrahman Wahid, 1999c: 197-198).

Wahid argued that politics, as a creation of the people, is worldly affairs without exception, including also Islamic politics. Accordingly, Muslims will not find any detailed guidance concerning the relationship between Islam and politics so that they are confronted with the plurality of the interrelationship between Islam and politics. Indeed, Wahid insisted on the role of Islam in the public sphere, but he argued that religion should play a complementary role, just providing a means for social transformation. It is, indeed, not religion which operates the course of liberation, regarding the fact that the world changes following its own laws. In this regard, Wahid did not want to see Islam become an alternative power: as soon as religion becomes a dominant, not influencing factor, it becomes worldly. Consequently, religion invites its followers to perform repressive actions for the sake of protecting religion, or more accurately, certain interpretations of religion (Abdurrahman Wahid, 1999d: 166-167). In this regard, an-Naim, a close friend of Wahid, in LibForAll, argued that:

By a secular state I mean one that is neutral regarding religious doctrine, one that does not claim or pretend to enforce Shari'a[h] — the religious law of Islam — simply because compliance with Shari'a[h] cannot be coerced by fear of state institutions or faked to appease their officials (Abdullahi Ahmed an-Na'im, 2008:1)

The idea of the secular nature of politics has strong justification from the fact that the validity of religious practices by Muslims was not related to their political party affiliation. Accordingly, Wahid argued that these two spheres need different leadership. This leadership separation was to guard against the historical repetition of the politicisation of religion or the intervention in religion by the state. In the case of Indonesia, this monolithic politics, Islam as an ideology, risked the distraction of the meaning of ummah when Islam was just associated with the followers of Islamic parties (Sidney Jones, 1984: 18).

Wahid did not agree with secularism, namely the classical theory of secularisation which would marginalise the role of religion just to a private matter. For Wahid, Islam is not just about ritual practices, but has a relationship with societal system, including political system. However, he did not want to unify both Islam and state system into a single identity as this contradicts the nature of societal life as worldly affairs, however, both should develop mutual legitimacy (Abdurrahman Wahid, 2001a: 27). By so doing, the state is run by state institutions, meanwhile religious affairs are managed by communities so that Islam does not function as the law of the state, but as a way of social life (Abdurrahman Wahid, 1989: 15).

Casanova, a moderate scholar, was more appreciative of the revival of religion in the 1990s, following the collapse of communism in the USSR. He proposed the thesis that secularisation is a differentiation of the secular sphere so that religion is one sphere among other spheres such as the economic and political. He believed religion is a crucial element for modernisation, although it is only one aspect of the public sphere. In this regard, Wahid's theory differs from Casanova's understanding of the fragmented role of religion in public life. Wahid believed that religion, namely Islam, should guide Muslims in daily life activities from private matters and into public matters, but the presence of Islam varies from one activity to another, depending on the type of social system. He did not believe in a monolithic Syari'ah which should be implemented by an Islamic state (Benyamin F. Intan, 2006: 17-18).

In line with the fiqh paradigm, Wahid believes that the nature of Syari'ah is a socio-cultural phenomenon that relates the spiritual to the material. He believes that the fulfilment of spirituality should be reached within the attainment of the material. For example, justice or freedom are not only abstract things, but should be materialised in society. This is due to spirituality being a principle of human beings, meanwhile the material things, namely the secular aspect of living, function as a medium for experiencing the spiritual (Chandra Muzaffar, 1989: 28-30).

\section{Subsumption of Syari'ah into the National Law}

In Wahid advocated the figh paradigm that Islam makes use of the existing societal systems, including the state, as a means of implementing Islamic teachings. This paradigm acknowledges the different manifestations of 
Islam based on the different cultures with their various social systems so that its supporters believe in the plurality of Syari'ah (Abdurrahman Wahid, 2007c: 20). In the case of Indonesia, Islam does not function as the foundation of the state, but as a social-ethical resource for the peaceful and harmonious running of the state. Islam justifies the Pancasila state as long as it provides Muslims with freedom to practice their religion.

Wahid believed that Islam, as a source of values, should guide all aspects of human beings, including politics. It does not imply a monolithic politics in the form of an Islamic party which struggles for power to establish an Islamic state (Abdurrahman Wahid, 2007b: 303). This subtle relationship between Islam and the state is consistent with the nature of Islam, recognising the dualism of the spirit and the material. The material is a medium for the spirit to manifest into reality. In line with this, Wahid considered the state is a kind of material which functions as a medium for implementing the Syari'ah. In regard with the form of the Pancasila state, it is impossible to materialize the legal formal Syari'ah, but rather the substantial form of Syari'ah, namely of its support for liberal democracy.

Wahid saw that Islamic law had lost its relevancy to the development of the modern era in Indonesia and it just played static roles to protect Islamic identity from the influence of non-Islamic values, especially secular ones. In this critique, Islam had a negative stance, namely rejecting any evils, misconducts, and wrong doings, and did not encourage people to do good things across a broad spectrum of meaning. This was due to the apologia characteristic of Islamic law, describing an idealistic worldview where Islamic law serves people with the happiness that comes both in this world and the hereafter. Put simply, it is like the city of God. As a result, Wahid argued:

For pursuing relevancy, Islamic law should be able to develop its dynamic characters for itself such as by positioning itself to support the development of national law in this development era. These dynamic characters are only possible if Islamic law emphasises its focus on and attention to worldly problems encircling this country right now and, then, provides solutions to actual problems facing the country right now. Accordingly, Islamic law is required to develop itself in a fluid situation (Abdurrahman Wahid, 1999d: 38-39).

Wahid held that Islamic law had an intrinsic orientation for its development which was not dependent on the will of a particular group. Accordingly, he confirmed D.B. MacDonald's saying "Law is greater than lawyers and it works in the end in justice and life" (Abdurrahman Wahid, 1999d: 50). This implied that Islamic law was not dependent on the role of the clerics, as Wahid also believed, but rather in the substantial Islamic law, in the form of universal values such as democracy, justice, and freedom. This kind of substantive Islamic law might be formulated by Parliament (Mujiburahman, 1999: 345). For that purpose, the clergy and Islamic scholars are challenged to keep track of the development of Western sciences, especially social sciences, so that they are able to find out the truth in the context of the modern era and understand theology in the new perspective (Abdurrahman Wahid, 1980: 7). This was to introduce the substantial meaning of Islamic laws, namely universal values, with the ambition of halting the secular trend of the modern era (Amos Funkenstein, 1986: 13).

Wahid had departed from the classical fiqh paradigm and embarked on the fiqh-plus paradigm as he incorporated the developments of modern science into the Islamic tradition. He interpreted the Islamic tradition in the light of modern knowledge and argued that Islam supports liberal democracy, considered as the implementation of the principle of syura (deliberation) in the modern context. This was due to his political approach to the relationship between Islam and the state which required the government to rule democratically. In line with this, Wahid developed his religious political thought in the form of democracy (Bahtiar Effendy, 2009: 9-11). He considered democracy as a kind of quasi-norm to resolve the tension between religion, namely Islam, as a norm from God, and the culture, the creation of human beings, including the state. Wahid asserted:

The recent difficult and complicated matter is how to resolve the tension encountered between religion (as a series of regulation) and culture (as process of changes). In my view, the most important thing for Islam now is how we formulate the standards about what we must do....In my view, the standard is very simple that everything that praises humanity must be supported. Its manifestation is to support human rights and develop a just societal structure.... The above standards play the role of quasi-norm (not a norm, but similar to a norm). If the development of culture or the period does not match with the above standards, we must stop them. Conversely, if religious teachings do not match with the above standards, we persist with the above standards (Abdurrahman Wahid, 2007a: 303).

Wahid rejected a legal formal approach that the state was to implement a legal Syari'ah, rather, he considered democracy as one of the substances of Syari'ah. He was sceptical of an Islamic state in which the ruler would operate democratically as the history of Islamic civilisation recorded that some caliphs and Sultans had ruled 
autocratically (Abdurrahman Wahid, 1989: 86). In line with this, he was also critical of the secular regimes, especially the Suharto regime, which tried to incorporate culture, including Islam, into the state. This was due to his belief that culture and Islam should function as forces critical of the state which naturally tends to be misused by the ruler (Abdurrahman Wahid, 2001b: 149).

Wahid's critical of an Islamic state also was based on the fact that Islamic unity was not maintained by the existence of a single Islamic state, but by Syari'ah (Islamic law). In this regard Wahid quoted S. H. Nasr who states that:

...the unity of Islam has been maintained by Syari'ah. Despite there being no single political power ruling over Muslims around the world, the same law is executed at Islamic courts in Morocco as well as in North India. It is the rule of the God's law which keeps maintaining the unity of the Islamic community as well as guaranteeing its Islamic character (Abdurrahman Wahid, 1999d: 51).

Regarding the status of the Republic of Indonesia which was similar to that of the Arab Republic of Egypt and the Republic of Iraq which were not Islamic states, but not secular states, Wahid was inspired to develop the role of Islamic law in Indonesia. As a Muslim, Wahid was very concerned with Syari'ah (Islamic law) and accordingly, early in his intellectual and political activist career in August 1975, he wrote an article entitled 'Making Islamic Law Conducive to Development'. Indeed, Islamic law, in the form of fiqh (the contextual Syari'ah), is very important in Muslim life since it legitimises Muslims' daily activities; it covers broader than Syari'ah implemented by the state (Abdurrahman Wahid, 1999d: 33-52).

Wahid recognised the limit of the concept of the nation state to implement Islamic law and he was very aware of this as the fiqh paradigm recognising the differentiation between Islam as a norm and the particularity of societal system as a medium for implementing the norms of Islam (Abdurrahman Wahid, 1990: 197-198). Accordingly, he argued that Indonesian Muslims should reformulate their aspiration for Syari'ah in terms of the concept of nation state as the basis of the Republic of Indonesia. For that purpose, he offered the substantive Syari'ah based on the theory of maqasid al-Syari'ah (the purposes of Islamic law) (Abdurrahman Wahid, 1999d: 46).

Wahid subsumed Syari'ah into the national law to resolve the existing conflict between the legal formal Syari'ah and the modern political system. This subsumption was different from that of the modernist Muslims who gave the government the right to arrange the life of Muslims, called the bureaucratisation of Islam by the state. Wahid did not agree with this kind of subsumption which implies giving power to the government so that the government becomes stronger than society. Of course, this idea of bureaucratisation of Islam was dangerous to democracy. On the contrary, Wahid had the idea of religious communities taking a role in civil society which provides checks and balances to the government.

Wahid's idea of subsumption was not in terms of bureaucratisation, but in the theological basis of Syari'ah by releasing its legal formal approach to the state and employing a political approach to the state as the context for implementing Syari'ah so that he did not want to establish an Islamic state, but a modern nation state. Accordingly, in the context of the Republic of Indonesia, Islam functions as an ethical bench-mark or standard through its universal values. By treating Islam as an ethical standard, Muslims will enable Islam to participate actively in the process of formulating the national law. Accordingly, this idea of subsumption maintains the clerics as the last resort of Islamic law, while not all material of Islamic law is related to state affairs (Abdurrahman Wahid, 1999d: 35).

Wahid's idea for subordinating Syari'ah within the national law and his advocacy for liberal democracy was aimed at overcoming an ineffective strategy pursued by the previous NU leaders, as well as other Muslim leaders, who had challenged the Suharto regime to rule by Islamic principles through political party lobbying, both directly and indirectly. In this regard, the previous NU leaders were also unable to attract wider support from Indonesians beyond the traditionalist Muslims as they developed their political arguments, specifically in Islamic terminologies (Abdurrahman Wahid, 1999d: 101).

Wahid also tried to develop religious communities into the role of civil society. For that purposes, he related Islam to the structural changes of society, but not at the level of the political system, only at its sub-system. What he meant by this societal structure was not outside the framework of Pancasila because it was not a matter of a political system, but of political culture, as he took Islam and the societal system as not being exclusive of each other, but rather interrelated with each other. For example, without questioning the Indonesian economic system, he tried to find a model for organising koperasi, an economic model with the original idea of bridging the two extreme economic systems of capitalist and socialist. Thus the challenge for Indonesian Muslims was to realise the idea of the Pancasila state and filled its political and economical systems with Islamic viewpoints which would change its people culturally. His idea implicitly criticised the Suharto regime which did not pay attention 
to lay people and tended to follow the capitalist system (Abdurrahman Wahid, 2001b: 150-151).

\section{Conclusion}

The figh paradigm was a kind of theory of a moderate secularisation as it provided a religious justification for the secular state, but the state should run following Islamic universal values such as democracy (syura), justice ( 'adl), and equality (musawah) considered as the substantive Syari'ah. To put it simply, Islam did not function as the law of the state, but a social ethic which guided the course of the state. The figh justified the state because of its function as a tool for establishing public order which constituted the pre-requirement for the establishment of religious order.

Wahid's thought on democracy is one manifestation of the fluid character of Islamic law suitable to the national political system and accordingly, it calls for a kind of subsumption of Syari'ah into the national law which enables Muslims to participate actively in the national political system for the purpose of the establishment of liberal democracy as the manifestation itself of the principle of syura.

At the same time, Wahid insisted the Suharto regime should rule following liberal democracy as a kind of quasi-norm and accordingly, he challenged the Suharto regime which advocated instead a theory of an integralistic state to maintain his power. He also campaigned that religious communities of different religions should play the role of civil society, providing checks and balances to the government.

\section{References}

Attas, S. M. N. al-. (1993). Islam and secularism. Kuala Lumpur: ISTAC.

Awan, M. K. (2011). Confusion on the concept of Islamic state and its resolution. Studying Islam, 1-11. Retrieved from http://studying-islam.org/articletext.aspx?id=1313

Badr El-din, E. \& Ould Cheikh, M. D. (2017). The military coups in shadow of democratization (A comparative study of Turkey and Mauritania). Asian Social Science. Vol. 13 (10), (pp. 75-85). URL: https://doi.org/10.5539/ass.v13n10p75

Beck, C. A. J., \& Sales, B. D. (2001). Family mediation: Facts, myths, and future prospects (pp. 100-102). Washington, DC: American Psychological Association. http://dx.doi.org/10.1037/10401-000

Bjork, R. A. (1989). Retrieval inhibition as an adaptive mechanism in human memory. In H. L. Roediger III, \& F. I. M. Craik (Eds.), Varieties of memory \& consciousness (pp. 309-330). Hillsdale, NJ: Erlbaum.

Casanova, J. (2007). Rethingking secularization: A global comparative perspective. In P. Beyer \& L. G. Beaman (Eds.), Religion, Globalization, and Culture. Leiden: BRILL.

Funkenstein, A. (1986). Theology and the scientific imagination: From the middle ages to the seventeenth century. Princeton: Princeton University Press.

Huntington, S/ P. (1993). The clash of civilizations. Foreign Affairs. 72 (3), (pp. 22-49).

Intan, B. F. (2006). "Public religion" and the Pancasila-based state of Indonesia: An ethical and sociological analysis. New York: Peter Lang Publishing, Inc.

Jones, S. (1984). The contraction and expansion of the "umat" and the role of the Nahdatul Ulama in Indonesia. Indonesia (38), (pp.1-20).

Monsma, S. V. (1996). Religious nonprofit organizations and public money: When sacred and secular mix. Maryland: Rowman \& Littlefield Publishers, Inc.

Mujiburrahman. (1999). Islam and politics in Indonesia: The political thought of Abdurrahman Wahid. Islam and Christian-Muslim Relations. 10 (3), 339-352.

Muzaffar, C. (1989). Al-Qur'an: Nilai dan peraturan [Al-Qur'an: Its values and its regulations]. Jakarta: P3M.

Na'im, A. A. an-. (2008). Islam and the secular state: Negotiating the future of shari'a. Cambridge, Massacushetts, London: Harvard University Press.

Nasution, A. B. (1992). The aspiration for constitutional government in Indonesia: A socio-legal study of the Indonesian Konstituante 1956-1959. Jakarta: Pustaka Sinar Harapan.

Norris, P. \& Inglehart, R. (2009). Sekulerisasi ditinjau kembali: Agama dan politik di dunia dewasa ini [Sacred and secular: Religion and politics worldwide]. (Z. Rofiqi, Trans.). Jakarta: Paramadina.

Wahid, A. (1980). Pribumisasi Islam [The Indonesianization of Islam]. In M. Azhari \& A. M. Saleh (Eds.), Islam Indonesia menatap masa depan [Indonesian Islam looks to the future]. Jakarta: P3M. 
Wahid, A. (1989). Pengantar [Introduction]. In E. M. Sitompul (Ed.), Nahdlatul Ulama dan Pancasila [Nahdlatul Ulama and Pancasila]. Jakarta: Sinar Harapan.

Wahid, A. (1999a). Agama dan demokrasi [Religion and democracy]. In Andito (Ed.), Politik demi Tuhan: Nasionalisme religius di Indonesia [Politics in the name of God: Religious nationalism in Indonesia] (pp. 367-370). Bandung: Pustaka Hidayah.

Wahid, A. (1999b). Islam di Asia Tenggara [Islam in Southeast Asia]. In Andito (Ed.), Politik demi Tuhan: Nasionalisme religius di Indonesia [Politics in the name of God: Religious nationalism in Indonesia]. Bandung: Pustaka Hidayah.

Wahid, A. (1999c). Mengurai hubungan agama dan negara [Elaborating the interface Islam and state]. Jakarta: Grasindo.

Wahid, A. (1999d). Prisma pemikiran Abdurrahman Wahid [Abdurrahman Wahid's thoughts in prisma]. (M. S. Isre Ed.). Yogyakarta: LKiS.

Wahid, A. (2001a). Indonesia's mild secularism. SAIS Review. 21(2). 25-28.

Wahid, A. (2001b). Menggerakkan tradisi: Esai-esai pesantren [Revitalizing the traditions of Islam]. Yogyakarta: LKiS.

Wahid, A. (2007a). Islam kosmopolitan: Nilai-nilai Indonesia dan transformasi kebudayaan [The cosmopolitan Islam: Indonesian Values and the cultural transformation]. Jakarta: Wahid Institute.

Wahid, A. (2007b). Islam, agama populer atau elitis? [Islam, populer or elite religion] In B. Dharmawan (Ed.), Gus Dur menjawab kegelisahan umat [Gus Dur answering the Muslims' controvercies]. Jakarta: Kompas.

Wahid, A. (2007c). Bagaimanakah membaca NU [NU and political power]. In B. Damawan (Ed.), Gus Dur membaca kegelisahan umat [Gus Dur answering the Muslims' controvercies]. Jakarta: Kompas.

\section{Copyrights}

Copyright for this article is retained by the author(s), with first publication rights granted to the journal.

This is an open-access article distributed under the terms and conditions of the Creative Commons Attribution license (http://creativecommons.org/licenses/by/4.0/). 